Article

\title{
Impact of the Construction Supplies Implementation on Road Safety in the City Center: A Case Study of the City of Szczecin
}

\author{
Oleksandra Osypchuk * and Katarzyna Sosik (1) \\ Faculty of Economics and Transport Engineering, Maritime University of Szczecin, ul. H. Pobożnego 11, \\ 70-507 Szczecin, Poland; k.sosik@am.szczecin.pl \\ * Correspondence: o.osypchuk@am.szczecin.pl
}

Citation: Osypchuk, O.; Sosik, K. Impact of the Construction Supplies Implementation on Road Safety in the City Center: A Case Study of the City of Szczecin. Sustainability 2021, 13, 1725. https://doi.org/10.3390/ su13041725

Academic Editor: Leise de Oliveira Received: 15 December 2020

Accepted: 1 February 2021

Published: 5 February 2021

Publisher's Note: MDPI stays neutral with regard to jurisdictional claims in published maps and institutional affiliations.

Copyright: (C) 2021 by the authors. Licensee MDPI, Basel, Switzerland. This article is an open access article distributed under the terms and conditions of the Creative Commons Attribution (CC BY) license (https:// creativecommons.org/licenses/by/ $4.0 /)$.

\begin{abstract}
The development of modern cities is impossible without an increase in the number of construction projects implemented. However, in the conditions of limited spaces, local and national legal regulations, and logistic difficulties, their implementation is becoming a growing challenge. Construction supplies can pose a particular problem. Its planning, organization, and implementation have an impact not only on construction and assembly works, but also on the external environment of the construction site, of which traffic is an important element. The aim of the study was to analyze and answer the question of whether there is a connection between the implementation of construction supplies and the occurrence of road traffic hazards in cities on the example of Szczecin. In addition, the article aims to find solutions to reduce the number of road accidents and increase road safety. The conducted research also revealed the weak points of the system of collecting and analyzing data on road accidents. The research covered selected areas in the center of Szczecin, where construction projects have been implemented since 2016 and road accidents have occurred. The reference year is the year preceding the start of construction. The research on selected construction projects meeting the criteria, carried out in the article has shown that their implementation may have an impact on the level of safety in the areas adjacent to the construction site. However, the unequivocal statement of such relationship must be supported by extended research, covering a greater number of projects, additional consideration of the number of deliveries for supply purposes, and the characteristics of vehicles involved in road incidents.
\end{abstract}

Keywords: city logistics; construction supplies; road safety

\section{Introduction}

Statistical data indicate a continuous increase in the migration of people from rural areas to cities. In 1950, only 30\% of the population was urban dwellers, by 2018 this figure was $55 \%$. According to estimates, by 2050 from $66 \%$ to $80 \%$ of the population will live in cities [1]. Now we have the opportunity to observe the next phase of urbanization, which is suburbanization. It is a phenomenon of urbanization in the suburban area. The increase in the level of urbanization and suburbanization indicate great development potential of urban and suburban areas. However, as the number of city dwellers increases, it is becoming increasingly difficult to meet their public service needs and maintain a high level of comfort.

With the increase in the level of urbanization, an increase in the volume of global goods exchange has been observed for decades, which directly translates into an increase in the role of freight terminals and distribution facilities. Supply chains are critical now and their number and complexity continue to increase. Internet access contributed to this, and caused radical changes in the structure of the supply chain [2]. Additionally, the human factor seems to be more important in the functioning of supply chains. Currently, supply chain stakeholders focus on meeting customer requirements, timely deliveries, and making sustainable decisions in order to survive in a competitive environment. In order to meet 
consumer expectations, companies have started to invest in projects aimed at sustainable development [3,4]. Stakeholder coordination and collaboration becomes essential to increase the efficiency of supply chains [5]. Cities are important in this as the place where the actors in the supply chain are functioning, and they are often the end point of delivery transport, becoming a place of last mile deliveries. Research in this area shows that the last miles contribute from $13 \%$ to $75 \%$ of all transport costs. Last mile logistics is often described as the wasteful, most expensive, and polluting air and environmental part of the supply chain [6]. Increasing the intensity of freight flow is exacerbating the problems of transport congestion, air and noise pollution, Greenhouse Gas (GHG) emissions, and the destruction of transport infrastructure and road accidents [7].

The high rate of urbanization and the development of its subsequent phases contribute to a continuous increase in demand on the real estate market, which determines the demand for construction services, both in city centers and suburban areas [8,9]. The market situation applies to all types of works: Construction of buildings (residential and non-residential), specialized construction works, and construction of civil engineering facilities.

Construction is becoming a key element in urban development. The economic situation in the industry determines the increase in the number of enterprises offering construction services and projects implemented by them [10]. This fact contributes to the increase in the number of freight transport for procurement purposes and causes an increase in conflicts between road users [11]. In the conditions of competition, enterprises strive to best meet the needs of customers in response to the growing requirements in terms of timeliness, quality, and individualization of implemented construction projects. All key actors in construction supply chains are increasingly using the concept of "just-in-time" for this purpose [12]. However, the faster development of the industry and the construction technologies used does not solve the problems associated with the negative impact of the implementation of construction projects on the functioning of cities. The negative effects accompanying the supply processes necessary for the implementation of construction projects are air pollution, exceeding the permissible noise emission standards, the occurrence of transport congestion and the impact on the level of road safety.

The aim of the study is to analyze and answer the question of whether there is a connection between the implementation of construction supplies and the occurrence of road traffic hazards in cities on the example of Szczecin. Due to the specificity of various types of construction works, only construction projects aimed at constructing buildings were qualified for the purposes of the article.

\section{Road Traffic Safety in Cities}

\subsection{Safety in the Context of Cities}

From the beginning of their creation, cities determined economic development and played a key role in the evolution of the world. In urbanized areas, there is social and economic potential that affects its efficient functioning and further development. Cities are a key place to meet the needs of society, such as education, mobility, place of residence, and workplace, the use of cultural opportunities and more. At the same time, the needs and expectations of society change, which is a challenge for their authorities. The needs can be divided according to their nature-material or non-material. The material needs include having a flat, car, food, while the non-material needs include, among others, social care, medical services, legal advice, and ensuring safety. Along with the dynamic progress of civilization, the needs of society are evolving as well, e.g., those requiring the provision of faster means of transport, more effective medicines, biodegradable and energy-saving materials, and technology that improves the sense of safety. Changes in the expectations of society are determined by the self-development of city dwellers and changes taking place in their structures. The contemporary society is described in the literature as a knowledge society or information society, thanks to the availability of Information and Communication Technology solutions, and the measure that intensifies this phenomenon is universal access to the Internet in almost every household [13-15]. 
One of the key needs of urban society are efficient movement and access to a wide range of consumer goods. Ensuring the effective functioning of the urban transport system affects the quality of life of its citizens. Society mobility is increasing as cities grow, resulting in more transport. Overloaded transport networks contribute to the negative effects of urban transport affecting the safety of citizens and their quality of life.

According to the available literature on the subject, there is a problem in the unambiguous and universal approach to defining the meaning of safety. The issues in this area result from the possibility of reference to many fields. Due to the society's need to learn about the genesis and specificity of the concept of safety and to clarify its definition, the intensification of scientific research in this area has sharpened [16]. According to the dictionary and encyclopedic literature, safety is considered in the context of public, collective, technical, and legal and political safety [17]. In the literature on the subject, one of the approaches to determining safety are considerations of its essence and evolution, allowing for division as a state and as a process [18]. Safety is also referred to as safety risk management, due to the inability to completely eliminate the human-guaranteed threat in the system [19]. The intensification of globalization processes significantly increases the expectations of society as to the desired level of safety. As a result of the globalization mentioned above, changes in the nature of threats and challenges posed for safety are observed [20].

In the context of road transport safety, it is defined as a system property that allows operation without undesirable occurrences under existing environmental conditions. The components of the system are human (as an operator), vehicle, environment. To increase safety, one can interact with each of the system components. According to statistics, man as an operator causes the largest number of threats. In addition, the components of the urban transport system in the context of safety are affected by non-material elements, including law, norms, strategies, and guidelines [21] (Volume I and II).

\subsection{The Importance of Safety in the Urban Road Transport System}

The efficiency of the urban transport system is one of the key elements conditioning its development. Its effective functioning activates the economy of the city and the whole country [22]. Road transport dominates in the urban transport system due to its specificitydoor to door, time, and quality [23]. Given the negative impact on the environment and society of this ever-growing transport industry, the European Union and the Member States have taken action to reduce its negative effects. However, these actions significantly put pressure, by the authorities and the public, on the automotive industry because the industry has great potential to solve environmental problems [24]. When creating the priorities for the urban transport system, the European Commission pays special attention to building an integrated system based on technology that will be friendly to the public. Projects aimed at introducing Vision Zero-elimination of road accidents involving injured and killed persons are increasingly used worldwide. One example is the use of integrated road safety system analysis, with an emphasis on the safety of vulnerable participants in North American cities. This technique allows the selection of potentially dangerous places in terms of road incidents in a more proactive way than on the basis of statistical data [25]. Each of the solutions that bring measurable benefits becomes an example of good practices for other cities. This is so important because the state of safety of the urban transport system is determined by human losses and material losses that are incurred as a result of catastrophes, accidents, and other accidents.

The increase in the number of motor vehicles in road traffic is a challenge to ensure the safety of vulnerable road users, including cyclists. Studies conducted over 20 years in London and published in 1996, 2010, and 2012 show that heavy trucks were the most common cause of fatal accidents with cyclists. Characteristic of this type of accident is the lack of injuries to heavy truck drivers and the incurring greater damage to the health of cyclists in such road accidents than in the case of an accident with a passenger car [26-28].

Poland as a member of the European Union also poses key challenges aimed at increasing transport safety. The condition of transport safety and the perspective of 
gradually implementing changes in the field of transport safety are presented in the White Book of National Security. One of the main assumptions is to eliminate the negative effects of transport. In particular, the transport congestion has an adverse effect on the transport system, as a result of which other transport problems accumulate, such as air pollution, noise, and road accidents $[23,29,30]$.

The most numerous losses in Poland expressed in the number of injured and fatalities are caused by road incidents in road transport [31]. The report on road accidents and safety is prepared annually by the Road Traffic Office of the Police Headquarters in Poland [32]. The report shows that the number of road accidents is gradually decreasing in Poland. The exception is 2016, when the number of road accidents reported increased, up to $2.76 \%$ more than the year preceding it. Table 1 presents data with the number of road accidents in the 2015-2018 period. Road accidents occurring in 2019 due to the lack of publicly available statistics were not included in the analysis.

Table 1. Total number of road accidents in Poland in 2015-2018 [32].

\begin{tabular}{ccc}
\hline Year & Number of Road Accidents & 2015-100\% \\
\hline 2015 & 32,760 & 100 \\
2016 & 33,664 & 102.7 \\
2017 & 32,967 & 100.63 \\
2018 & 31,674 & 96.68 \\
\hline
\end{tabular}

There are many factors that affect the number of road accidents. These include the time of year, time of occurrence, day of the week, time of day, as well as prevailing weather conditions. However, the nature of road accidents is mainly influenced by the place of occurrence. In the analyzed period, there were more accidents in built-up areas than in non-built-up areas. The most common type of accident is the collision of vehicles in motion, which is characteristic for the urban transport system. However, the consequences of accidents in undeveloped areas are several times greater [32]. Table 2 shows the number of road accidents that occurred in built-up and undeveloped areas, respectively.

Table 2. Number of road accidents in built-up and non-built-up areas in Poland in 2015-2018 [32].

\begin{tabular}{ccc}
\hline Year & $\begin{array}{c}\text { Number of Road Accidents in } \\
\text { Built-Up Areas }\end{array}$ & $\begin{array}{c}\text { Number of Road Accidents in } \\
\text { Undeveloped Areas }\end{array}$ \\
\hline 2015 & 23,658 & 9309 \\
2016 & 23,869 & 9795 \\
2017 & 23,262 & 9498 \\
2018 & 22,560 & 9114 \\
\hline
\end{tabular}

Due to the rapid progress of urbanization in cities, built-up areas are expanding as a result of growing construction activities. Consequently, urban construction investments contribute to an increase in the number of transported goods as a result of the necessary supply processes. The occurrence of additional transport in urban transport systems may constitute an additional element affecting safety.

\subsection{Literature Summary and Contribution}

The issue of road safety is widely discussed in the literature. McDonald N. et al. examined the trend in the safety of urban transport in 2005-2015 in the United States. The number of road accidents and their characteristics related to freight transport in cities were analyzed, and these data were compared with other types of road accidents. The results of the research confirmed the hypothesis that cargo vehicles constitute an increasing impact on safety in urban areas [33]. another analysis was presented by CastilloManzano J. et al., studying the relationship between truck payload and road accidents. The considerations divide trucks into three categories: Heavy, medium, and light. The study 
was carried out on the example of several EU Member States. The obtained results indicate that the load capacity of trucks has an impact on road safety, but it is non-linear and depends on the type of road accident. Light trucks perform the worst in terms of the number of road accidents, while medium trucks perform the worst in terms of the number of fatalities in road accidents [34]. On the other hand, heavier-duty vehicles can reduce road traffic by increasing the carrying capacity of fewer vehicles, which may have an impact on road safety [35]. Other features of trucks indicating their impact on the occurrence of road traffic hazards, apart from their weight and size, are operational properties, such as braking distance [36].

The European Union pays special attention to the aspect of road safety. The initiatives taken by the European Commission concern the reduction of the number of accidents on European roads. The overall number of fatalities and serious injuries on roads in EU members has stagnated. Hence, the European Commission is in the phase of implementing a secure system, which is to achieve the zero vision by $2050[37,38]$. This system is about safe vehicles and infrastructure, lower road speeds, and better healthcare after accidents, as well as better use of protective equipment. The European Union has come up with a proposal to develop new ways of supporting countries with poor road safety performance. The number of fatalities in accidents in Poland per million inhabitants was 76 in 2018 and 77 in 2019. EU countries have shown an improvement in the absolute number of deaths per million inhabitants over this period, for example, Luxembourg (39\% less), Sweden (32\% less), and Estonia ( $22 \%$ less). The changes that have taken place over the last decade are much more positive, and the decrease in the number of deaths per million inhabitants was approximately $26 \%$ in Poland. This result exceeds the overall changes that have occurred in all member countries [38].

Unprotected road users, including pedestrians, cyclists, and motorcyclists, suffer the most serious consequences in accidents. This group of participants in the second movement most often becomes the subject of interest to decision-makers. This is due to the limited ability to protect against the speed and weight of road vehicles. In quantitative studies presented by Torfs K. and Meesmann U., pedestrians from the entire group of vulnerable road users feel the least safe [39]. Over the past decade, many studies and initiatives have been developed to support the safety of unprotected road users, especially pedestrians [40]. EU statistics show that pedestrians are killed most in a road accident compared to bicycle and motorcycle users [41]. According to the World Health Organization, unprotected road users will be responsible for half of the world's fatal accidents [42].

However, there is little research on the impact of construction projects on road safety in the literature. The complexity of the topic requires much more research in this area. A literature review shows that there is a correlation between the type of vehicle and the injuries sustained in road accidents involving them. They also indicate the need to consolidate goods in order to reduce road traffic in cities, thus contributing to increased safety and reduction of emissions. It seems justified to fill the research gap related to the implementation of construction supplies, and its impact on the transport system, because transport activities related to construction supplies have a negative impact on the environment and general city logistic. CE Delft research indicates that 25\% of GHG emissions at city logistics of Duch is related to construction activities, in Amsterdam 15\% to $20 \%$ of all heavy supplies are associated with construction. Such a large share of freight transport related to construction investments contributes to increasing noise, pollution, mobility problems of residents, and reducing the level of safety of all road users [43].

\section{Construction Supplies in the Context of Its Impact on Road Traffic in the City Center}

\subsection{Logistics of Construction Projects}

Constructions is a specific kind of project-based industry. Each building object is unique or considered to be unique. Construction projects are treated as cooperation of companies to implement a single project, which forces enterprises to act as one entity with a common goal. The main contractor is to understand the differences between the 
various contractors and coordinate their activities in an efficient and effective manner [44]. Logistics is one of the areas difficult to coordinate and manage.

Logistics of construction projects involves handling material, cash, information, human resources flows, spatial and time planning, creating schedules, and coordinating activities, and thus constitutes an important part of the entire construction process [45]. Due to assembly, construction, legal and geographical conditions, logistics present a serious challenge for contractors.

Logistics must be treated as an integral element, as only this approach allows the efficiency of the entire process and economic benefits [46]. The efficiency and effectiveness of implemented logistics processes becomes particularly important when implementing construction investments in the city center. In the context of the implementation of construction projects, supply logistics occupy a key place in comparison to other areas, due to their special impact on the timeliness, quality, and costs of ongoing works.

\subsection{Implementation of Construction Supply in Cities and its Impact on Traffic in the City Center}

The task of supply logistics is to provide the right amount of the right materials and tools to the right place at the right time, the right quality, and the lowest possible price. The organization of supply logistics in construction is specific, and often difficult to coordinate due to the nature of construction activities. Difficulties are presented both by the large number of subcontractors, the size of the construction project, the priorities of the main contractor, as well as difficulties related to financial liquidity [47]. Another problem is the location of the construction project, which also determines the entire supply planning and implementation process.

The implementation of construction supplies requires a large number of strategic decisions from the main contractor. They concern, among others, the selection of a form of supply that is appropriate to the needs: Centralized, dispersed, mixed supply, or implemented with logistic organs [48]. In addition, a decision must be made whether to store materials, stock levels, or use the Just-in-Time concept. In the case of implementation of construction projects within city limits, planning and implementation of transport for the purposes of building supply are particularly important [49].

Transport activities related to construction supplies have a negative impact on the environment. CE Delft research indicates that $25 \%$ of GHG emissions at city logistics of Duch is related to construction activities, and in Amsterdam, 15\% to $20 \%$ of all heavy supplies are associated with construction. Such a large share of freight transport related to construction investments contributes to increasing noise, pollution, mobility problems of residents, and reducing the level of safety of all road users [43].

Supplying for the implementation of construction projects in cities must be adapted to the legal requirements in the field of construction and assembly works, as well as the adopted local transport policy. Elements of local transport policy affecting transport for construction supplies are time restrictions on the entry of selected vehicle classes, entry bans, and time restrictions on parking [50]. In addition, temporary or permanent changes in land use are a problem, as they contribute to exerting a negative impact on the existing transport system in the form of congestion, obstructions in road traffic, and infrastructure degradation [51]. Such conditions determine the need for planning building supply together with the road manager. Their cooperation consists in joint route planning, scheduling and redirecting traffic flows, or closing selected road sections. All the abovementioned factors can be an element affecting the occurrence of threats in the urban transport system.

\section{Accident Analysis in Szczecin in 2015-2018}

\subsection{Problems of the Transport System in Szczecin}

Szczecin as the capital of the West Pomeranian region is the main transport hub. It is the third city in Poland with the largest area occupied, right after Warsaw and Krakow. Szczecin is in close proximity to the Polish-German border. The geographical location 
for access to the mouth of the Odra River, Szczecin Lagoon and Lake Dabie enables the development of the port sector $[52,53]$. Due to its transit location, the city faces many transport problems. The main negative factor affecting the urban transport system is transport congestion. As a result, road congestion generates further problems of the urban transport system [54].

In response to the problems of the urban transport system in Szczecin, many projects have been created, the aim of which was to improve the functioning of road traffic and urban transport, regarding the improvement of safety of individual road users, improving road capacity and efficiency of both passenger and freight transport. One of such projects was "Construction of a Traffic Management System in Szczecin". The project started in the second half of 2011. This project aimed to improve traffic flow on access roads to the city center in accordance with existing transport corridors. The Traffic Management System is based on telematics systems technologies. They were designed, installed, integrated, and launched using an application layer and an executive layer. The application layer consists of subsystems along with the Municipal Transport Management System [51,55].

\subsection{Accident Analysis in the West Pomeranian Voivodeship and in Szczecin in 2015-2018}

Data on road accidents in Poland are collected and published by the police. In this part of the article, statistical data is analyzed descriptively. The number of road accidents in the West Pomeranian Voivodeship and in Szczecin in the period from 2015 to 2018 showed a downward trend. For the West Pomeranian voivodship, the exception was 2016, and for Szczecin 2017, when the largest number of accidents occurred over the analyzed period. In relation to the entire country, the number of accidents is also decreasing in the discussed period, however, in 2016, their slight increase was recorded. The total number of accidents from 2015 to 2018 for the West Pomeranian and Szczecin are presented in Table 3. These data include additionally the number of fatalities and injuries. With the increase in the number of accidents has increased the number of injured [56].

Table 3. Number of road accidents in the West Pomeranian region and the city of Szczecin in 2015-2018 [56].

\begin{tabular}{ccccccccc}
\hline \multirow{2}{*}{ Year } & \multicolumn{2}{c}{ Number of Road Accidents in West Pomeranian Region } & \multicolumn{3}{c}{ Number of Road Accidents in Szczecin } \\
\cline { 2 - 8 } & Total & $\mathbf{2 0 1 5 - 1 0 0 \%}$ & Injured & Fatalities & Total & 2015-100\% & Injured & Fatalities \\
\hline \multirow{2}{*}{2015} & 1298 & 100 & 1470 & 125 & 556 & 100 & Lack of & Lack of \\
data & data & 525 & 10 & 539 & 10 \\
2016 & 1332 & 102.62 & 1608 & 149 & 455 & 81.83 & 92.44 & 495 \\
2017 & 1232 & 94.92 & 1435 & 120 & 514 & 78.96 & 12 \\
2018 & 1183 & 91.06 & 1358 & 129 & 439 & \\
\hline
\end{tabular}

At the end of the 20th century, the number of registered vehicles was systematically increased in Poland. This trend is also recorded in the West Pomeranian Voivodeship. Table 4 presents data on the number of registered vehicles in the West Pomeranian Voivodeship, as well as the number of accidents, the number of fatalities, and the number of injuries per 10,000 vehicles. The indicator of the number of fatalities and the number of injured per 100 road accidents has also been added for both the West Pomeranian Voivodeship and Szczecin. By analyzing the data, it can be concluded that despite the increase in the number of registered vehicles, the level of road safety is increasing. When referring to the indicators calculated for Szczecin, there is no clear downward trend. The increase in the number of road accidents contributed to the increase in injuries [56,57]. 
Table 4. Safety status indicator depending on the number of registered vehicles [56].

\begin{tabular}{|c|c|c|c|c|}
\hline Year & 2015 & 2016 & 2017 & 2018 \\
\hline Number of registered vehicles in the West Pomeranian Voivodeship & 873,045 & 911,812 & 946,400 & 984,182 \\
\hline Accident rate per 10,000 vihicles in the West Pomeranian Voivodeship & 14.9 & 14.6 & 13.0 & 12.0 \\
\hline Injury rate per 10,000 vehicles in the Pomeranian Voivodeship & 1.7 & 1.8 & 1.5 & 1.4 \\
\hline Fatalities per 10,000 vehicles in the West Pomeranian Voivodeship & 1.4 & 1.6 & 1.3 & 1.3 \\
\hline $\begin{array}{l}\text { Indicators of the number of injured per } 100 \text { road accidents in the West } \\
\text { Pomeranian Voivodeship }\end{array}$ & 113.3 & 120.7 & 116.5 & 114.8 \\
\hline $\begin{array}{c}\text { The number of fatalities per } 100 \text { road accidents in the West Pomeranian } \\
\text { Voivodeship }\end{array}$ & 9.6 & 11.2 & 9.7 & 10.9 \\
\hline Indicators of the number of injured per 100 road accidents in Szczecin & Lack of data & 115.4 & 104.9 & 1.9 \\
\hline The number of fatalities per 100 road accidents in Szczecin & Lack of data & 2.2 & 1.9 & 2.7 \\
\hline
\end{tabular}

In the area of the West Pomeranian Voivodeship, the statistics include the type of vehicle of the perpetrator of the road accident. In the analyzed period, the greatest number of accidents were caused by the fault of passenger car drivers. There were several times fewer road accidents caused by drivers of trucks, motorbikes, bicycles, and public transport buses [56].

Research on road traffic is carried out by various institutions in Szczecin. In 2016, the traffic volume in Szczecin should be measured by the Szczecin City Hall [58]. Every 5 years, general road traffic measurement is carried out by the General Directorate of Roads and Motorways, and data are collected throughout the country. From the published report in 2020, there were seven measuring points in the city of Szczecin, and each of them was located on exit roads [59]. Lack of systematization of the collection of output data looks like a big problem for analysis [60].

\section{The Impact of Construction Supplies on Road Safety}

\subsection{Research Methodology}

In pursuit of the research goal, the data triangulation method was used, which allowed the authors to take a broader look at the subject of the study, both in time and spatial perspective. The choice of the research method was determined by the possibility of collecting complete data for analysis while eliminating subjectivity. By combining different methods, authors in one study avoid the lack of accuracy resulting from the use of one method.

Desk research and statistical data analysis were carried out. In addition, structured observation and structured interview with contractors was used to select study objects. The research covered construction projects implemented since 2016. The selection of the examined objects was based on the following criteria: Location, occurrence of "bottlenecks", size of the building, number of subcontractors, type of construction, duration of the project.

The analysis of road accidents in the area of selected construction projects in the city of Szczecin is possible only in terms of the characteristics of their occurrence. A limitation of the study is that participants can become perpetrators of road accidents. The data on road accidents collected in Poland has numerous limitations and shortcomings. One of them are road incidents that have not been notified to the relevant services. Referring to the good practices of other countries, attention should be paid to the detail of road accidents depending on the injuries sustained by the injured, providing information about the vehicle involved in the accident and many other factors [61].

The article is organized as follows. In addition to the introduction, Chapter 2 is divided into three parts and covers road safety in cities. Chapter 3 is divided into two parts, and discusses construction procurement in terms of its impact on urban traffic. Chapter 4 presents an analysis of road accidents based on the example of the examined city. Chapter 5 presents the study of the impact of construction supplies on road safety. Finally, Chapter 6 presents the conclusion. 


\subsection{Characteristics of the Research Sample}

The research was conducted in the city of Szczecin, which is a city with powiat rights, the capital of the West Pomerania, and the largest city in the region [62]. Szczecin is a rapidly growing metropolis characterized by economic development, which contributes to the increase in the number of construction projects implemented. Recent years have also been characterized by a growing number of construction companies carrying out all types of construction works in the city. At the end of 2015, their number was 7764. At 1 of September 2019, this number was already 8453 [10], which means an increase of about $8.9 \%$.

The article takes into account the location of the construction projects carried out in the area of the city center of Szczecin, in the area covering a large part of enterprises, shopping centers, administrative buildings, schools, universities, and other key units. The difficulty in designating the city center in Szczecin resulted from its polycentric structure [63]. In Szczecin, there are no general restrictions on the possibility and hours of truck entry into the city. These restrictions only apply to certain streets. For research purposes, the qualified construction projects did not have such restrictions.

To standardize the research sample, only construction works related to the erection of buildings and specialized construction works (Polish Classification of Activities (PKD) F41 and F43) were considered in the article. An additional criterion for choosing construction projects was their type. Only residential and non-residential buildings were considered (Section 1 of the Polish classification of buildings). For research purposes, all facilities were also divided by size (small to $999 \mathrm{~m}^{2}$, medium from 1000 to $9999 \mathrm{~m}^{2}$, large from 10,000 $\mathrm{m}^{2}$ ). Medium and large construction projects were qualified for the study due to the amount and kind of supplies needed for the supply. Standardization of the research sample also made it possible to determine the type of deliveries carried out during construction. Masonry and plastering, concrete, painting, roofing, welding, and other works were performed on all facilities. Supply for the purposes of their implementation was realized both directly from material producers and construction wholesalers. Depending on the size, deliveries were made both by transport up to 3.5 tons and by high-tonnage transport. Due to the uniformity of the sample, the types of building materials supplied were not included in the study.

Construction projects were also analyzed in terms of the number of subcontractors. Construction carried out by 0-9 subcontractors was considered to be carried out with a small number of subcontractors, from 10 to 19 as implemented by the average number of subcontractors, 20 and more as carried out by a large number of subcontractors. The number of subcontractors may affect the number of deliveries carried out. For qualified construction projects, areas adjacent to the construction site have been determined, which may be affected by the implementation of transport for supply purposes. Adjacent streets and intersections were taken as such areas.

\subsection{Results of Study on the Impact of Construction Supply on Road Safety}

The construction projects selected for the study are presented in Figure 1. According to the adopted criterion, they are located in the city center, close to the so-called bottlenecks. All objects met the assumed research criteria. Table 5 presents the detailed characteristics of selected construction investments.

Particularly noteworthy is the fact that the implementation of the Hanza Tower began in 2011, but it was only in 2012 that the first works began. In Spring 2013, at the preparatory stage, construction was suspended. It was not until 2017 that the work was resumed [64]. 


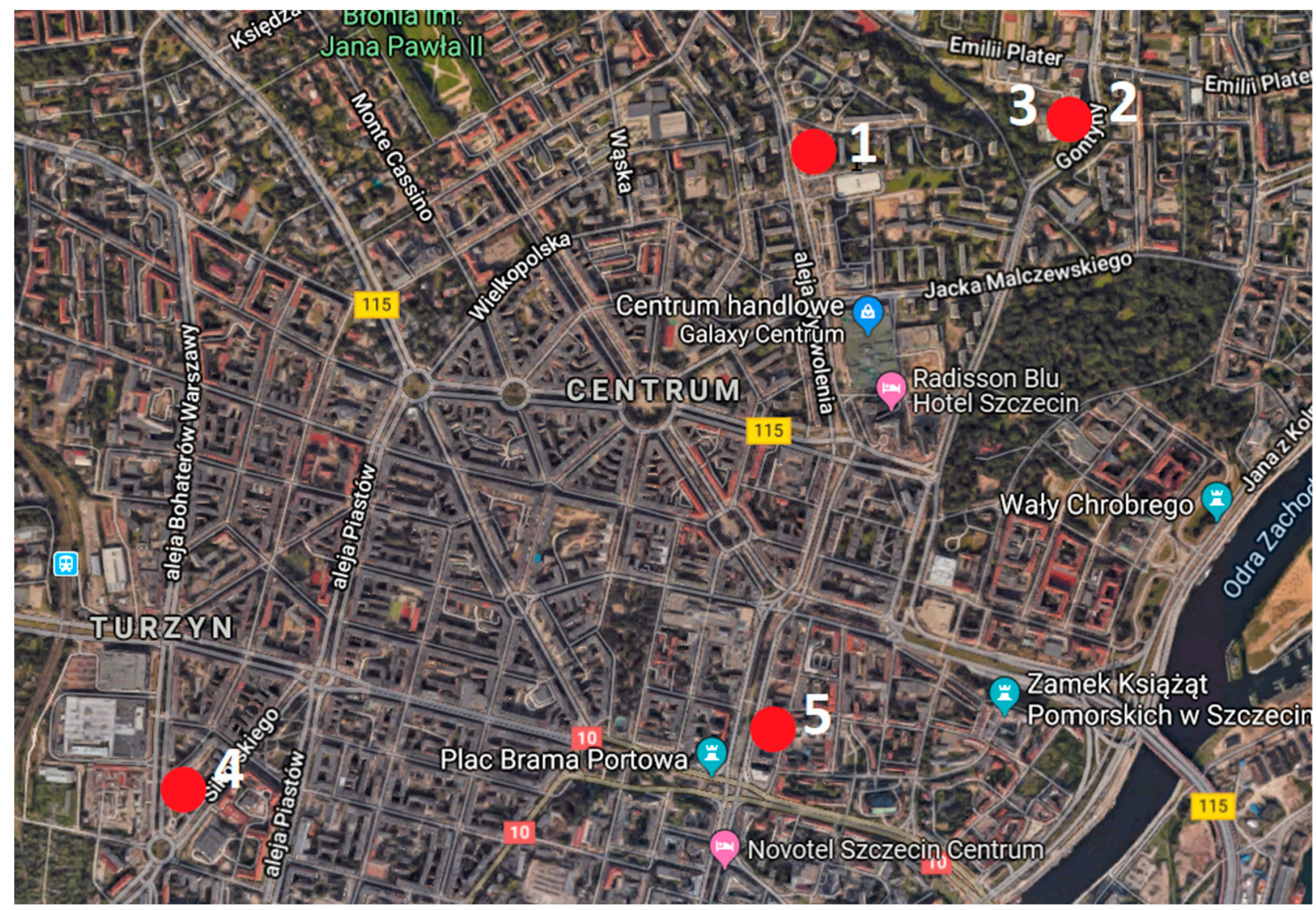

Figure 1. Location of construction projects selected for the study [own study map Google], 1-Hanza Tower; 2-Nautica III; 3-Nautica IV; 4-Hurt market; 5-Black Pearl.

Table 5. Characteristics of selected construction projects and own study [64].

\begin{tabular}{|c|c|c|c|c|c|c|}
\hline No & Name & Type of Object & Beginning & Ending & $\begin{array}{c}\text { No. of } \\
\text { Subcontractors }\end{array}$ & Size \\
\hline 1 & Hanza Tower & $\begin{array}{c}\text { Residential with } \\
\text { commercial and service } \\
\text { part area }\end{array}$ & $\begin{array}{l}2011 \text { (suspended } \\
\text { in 2013, resumed } \\
\text { in 2017) }\end{array}$ & $\begin{array}{l}\text { Planned } \\
\text { for } 2020\end{array}$ & Large number & Large (usable floor area $54,337 \mathrm{~m}^{2}$ ) \\
\hline 2 & Nautica III & Residential & 2016 & 2017 & Large number & Medium (total area of $4500 \mathrm{~m}^{2}$ ) \\
\hline 3 & Nautica IV & Residential & 2017 & 2018 & Large number & Medium (no accurate data) \\
\hline 4 & $\begin{array}{l}\text { Reconstruction } \\
\text { of the Hurt } \\
\text { market }\end{array}$ & Commercial and service & 2016 & 2017 & Small number & Large (total area $13,000 \mathrm{~m}^{2}$ ) \\
\hline 5 & Black Pearl & $\begin{array}{c}\text { Residential with office, } \\
\text { commercial, and service } \\
\text { part }\end{array}$ & 2016 & 2018 & Small number & Large (total area $11,000 \mathrm{~m}^{2}$ ) \\
\hline
\end{tabular}

To determine the changes in the level of safety in areas adjacent to construction sites, the number of accidents in the year preceding the year of construction beginning was examined, as well as the average number of accidents per year during the construction investment. For research purposes, in the case of Hanza Tower, 2016 was adopted as the year preceding the start of construction (the year before work resumed). Table 6 shows the number of road accidents before construction projects are started and the average number of road accidents during construction and their characteristics. 
Table 6. Number of road accidents and their characteristics before and during construction $[56,64]$.

\begin{tabular}{cccccc}
\hline No. & Name & $\begin{array}{c}\text { Number of } \\
\text { Accidents Before } \\
\text { Construction }\end{array}$ & $\begin{array}{c}\text { The Most Common Types of } \\
\text { Accidents Before the } \\
\text { Implementation of } \\
\text { the Investment }\end{array}$ & $\begin{array}{c}\text { Average Number of } \\
\text { Accidents During } \\
\text { Construction } \\
\text { per Year }\end{array}$ & $\begin{array}{c}\text { Most Common Types of } \\
\text { Accidents During the } \\
\text { Implementation of } \\
\text { the Investment }\end{array}$ \\
\hline 1 & $\begin{array}{c}\text { Hanza Tower } \\
\text { Nautica III }\end{array}$ & 1 & $\begin{array}{c}\text { Car-to-pedestrian accidents } \\
\text { Side/rear/frontal collision } \\
\text { Side/rear/frontal collision and } \\
\text { car-to-pedestrian accidents }\end{array}$ & 2.5 & $\begin{array}{c}\text { Side/rear/frontal collision } \\
\text { Side/rear/frontal collision and } \\
\text { car-to-pedestrian accidents }\end{array}$ \\
3 & $\begin{array}{c}\text { Nautica IV } \\
\text { Reconstruction } \\
\text { of the Hurt } \\
\text { market }\end{array}$ & 1 & Car-to-pedestrian accidents & 1 & Side/rear/frontal collision \\
5 & Black Pearl & 1 & Other & 2 & None \\
\hline
\end{tabular}

In the case of Hanza Tower and Black Pearl, the average number of accidents during construction was higher than in the year preceding the start of the project. Research results regarding Nautica III indicate that the number of accidents was similar. During the implementation of Nautica IV, the number of accidents has significantly decreased. The number of road accidents in areas adjacent to the reconstruction square of the Hurt market was 0 , and one road incident was noted in the year preceding the reconstruction. These results may be related to the location characteristics of the implemented construction project. The close occurrence of only a roundabout and a two-lane two-way road without the possibility of turning may reflect the above result. The most common road accidents were side/rear/frontal collisions. Equally frequent were car-to-pedestrian accidents.

\section{Conclusions}

The implementation of construction projects in cities is a serious challenge for contractors both due to the specificity of the works and organizational difficulties, especially in the field of construction supply. An additional problem is safety, which must be ensured not only on the construction site, but also in the adjacent areas. Due to the frequent need for changes related to temporary and permanent land use, all road users may be additionally exposed to road hazards. For this reason, the aim of the article was to analyze and answer the question whether there is a connection between the implementation of construction supplies and the occurrence of road traffic hazards in cities on the example of Szczecin. In addition, the article aims to find solutions to reduce the number of road accidents and increase road safety. The conducted research also revealed the weak points of the system of collecting and analyzing data on road accidents. The research covered selected areas in the center of Szczecin, where construction projects have been implemented since 2016 and road accidents occurred. The reference year is the year preceding the start of construction.

Five selected construction projects were qualified for the study, meeting specific criteria, which included: Location, type of building, size, type of performed works, number of subcontractors. Depending on the size, deliveries were made both by transport up to 3.5 tons and by high-tonnage transport. The study on five selected construction projects meeting the criteria has shown that their implementation may have an impact on the level of safety in the areas adjacent to the construction site. The most common road accidents were side/rear/frontal collisions. Equally frequent were car-to-pedestrian accidents. However, the unequivocal statement of relationship between implementation of construction projects and level of safety must be supported by extended research, covering a greater number of projects, additional consideration of the number of deliveries for supply purposes and the characteristics of vehicles involved in road incidents, as well as their detailed description. An important aspect in the analysis of the relationship between the implementation of construction projects in cities and the accident rate is the length of construction investments and stages of construction.

In order to increase road safety in the context of ongoing delivery transport for construction supply purposes, it seems reasonable to expand the infrastructure surrounding the construction site with particular emphasis on unloading places, optimize the supply system, and implement solutions in the field of transport telematics, both in infrastructure 
elements and means of transport. In addition, the results of the Australian study on implementing high productivity freight vehicles in urban areas [65] show the need for consolidation of supplies to reduce the number of accidents.

As part of the research, it turned out that there is a serious problem related to the process of collecting and analyzing data related to the level of road safety. The available data is scattered, incomplete and, above all, does not take into account vehicle classification. It seems justified to extend the scope of collecting various data by competent authorities. It is helpful to locate road accidents on the map with the description of the accident occurrence characteristics, date, and time. However, it seems reasonable to extend them with information about the perpetrator of the accident, such as gender and age, as well as describing road conditions and visibility [60,61]. It seems reasonable to follow the experience of collecting data in other cities, e.g., in Abu Dhabi where descriptive statistics of data collected by the police contains a breakdown of road accidents according to the variable such as: Gender, age category, seat belts, seat damage, road classification, speed limit, lanes, and type of accidents [66].

The practice of other countries shows that the larger data sets we have, the more efficiently and effectively we can select and implement various types of solutions. The implementation of activities aimed at sustainable development, such as reducing noise and greenhouse gas emissions, requires access to up-to-date data. They can significantly support local authorities in taking action in the context of urban logistics. The more that the subject of data collection and processing is common, and setting goals to reduce the negative effects of the urban transport system has become a priority for city, state, and EU managers.

The research carried out for the purpose of this article indicated the need to continue and deepen the research on the impact of the implementation of construction supplies on the level of road safety in order to unequivocally establish the dependencies. In addition, the need to transfer the detected defects in the collection and analysis of accident data to appropriate authorities for the purpose of improvement and improvement was indicated.

Author Contributions: Conceptualization, O.O. and K.S.; methodology, O.O. and K.S.; validation, O.O. and K.S.; formal analysis, O.O. and K.S.; investigation, O.O. and K.S.; resources, O.O. and K.S.; data curation, O.O. and K.S.; writing—original draft preparation, O.O. and K.S.; writing-review and editing, O.O. and K.S.; visualization, O.O. and K.S.; supervision, O.O.; project administration, O.O.; funding acquisition, O.O. and K.S. All authors have read and agreed to the published version of the manuscript.

Funding: This research was funded by MARITIME UNIVERSITY OF SZCZECIN, grant number 1/S/WIET/PUBL/21.

Institutional Review Board Statement: Not applicable.

Informed Consent Statement: Not applicable.

Data Availability Statement: Data sharing not applicable.

Conflicts of Interest: The authors declare no conflict of interest.

\section{References}

1. United Nation. World Urbanization Prospects, The 2018 Revision. 2019. Available online: https://population.un.org/wup/ Publications /Files/WUP2018-Report.pdf (accessed on 21 November 2019).

2. Zhu, L.; Ren, X.; Chulung, L.; Zhang, Y. Coordination Contracts in a Dual-Channel Supply Chain with a Risk-Averse Retaile. Sustainability 2017, 9, 2148. [CrossRef]

3. Theophilus, O.; Dulebenets, M.A.; Pasha, J.; Abioye, O.F.; Kavoosi, M. Truck Scheduling at Cross-Docking Terminals: A Follow-Up State-Of-The-Art Review. Sustainability 2019, 11, 5245. [CrossRef]

4. Dong, C.; Li, Q.; Shen, B.; Tong, X. Sustainability in Supply Chains with Behavioral Concerns. Sustainability $2019,11,4051$. [CrossRef] 
5. Guo, F.; Liu, Q.; Liu, D.; Guo, Z. On Production and Green Transportation Coordination in a Sustainable Global Supply Chain. Sustainability 2017, 9, 2071. [CrossRef]

6. Olsson, J.; Hellström, D.; Pålsson, H. Framework of Last Mile Logistics Research: A Systematic Review of the Literature. Sustainability 2019, 11, 7131. [CrossRef]

7. Bosona, T. Urban Freight Last Mile Logistics-Challenges and Opportunities to Improve Sustainability: A Literature Review. Sustainability 2020, 12, 8769. [CrossRef]

8. Zhang, Y.; Song, R.; van Nes, R.; He, S.; Yin, W. Identifying Urban. Structure Based on Transit-Oriented Development. Sustainability 2019, 11, 7241. [CrossRef]

9. Harasimowicz, A. Suburbanizacja a rola obszarów otaczajacych miasto-ujecie teoretyczne. Stud. Miej. 2018, 29, 115-130. [CrossRef]

10. Główny Urząd Statystyczny. Available online: https:/ / stat.gov.pl (accessed on 23 November 2019).

11. Pitera, K.; Pokorny, P.; Kristensen, T.; Bjørgen, A. The complexity of planning for goods delivery in a shared urban space: A case study involving cyclists and trucks. Eur. Transp. Res. Rev. 2017, 9, 46. [CrossRef]

12. Dulebenets, M.A. A Diploid Evolutionary Algorithm for Sustainable Truck Scheduling at a Cross-Docking Facility. Sustainability 2018, 10, 1333. [CrossRef]

13. Kijewska, K.; Iwan, S.; Korczak, J. Challenges to increase the sustainable urban freight transport in South Baltic Region-LCL project. Transp. Res. Procedia 2019, 39, 170-179. [CrossRef]

14. Mansell, R. The information society and ICT policy: A critique of the mainstream vision and an alternative research framework. J. Inf. Commun. Ethics Soc. Source 2009, 8, 22-41. [CrossRef]

15. Stawacz, D. Wspótczesne Dylematy Zarządzania Rozwojem Miast; Wydawnictwo Uniwersytetu Łódzkiego: Lódź, Poland, 2016; pp. 17-24.

16. Czupryński, A.; Wiśniewski, B.; Zboina, J. Bezpieczeństwo. Teoria-Badania-Praktyka; Wydawnictwo CNBOP-PIB: Warszawa, Poland, 2015; pp. 9-10. Available online: https://www.cnbop.pl/wydawnictwa/ksiazki/978-83-61520-26-9/bezpieczenstwo.-teoriabadadnia-praktyka.pdf (accessed on 22 October 2019).

17. Petrozolin-Skowrońska, B. (Ed.) Nowa Encyklopedia powszechna PWN; Wydawnictwo Naukowe PWN: Warszawa, Poland, 1996; Volume IV, Available online: https:/ / encyklopedia.pwn.pl/encyklopedia/bezpiecze\%C5\%84stwo.html (accessed on 23 November 2019).

18. Koziej, S. Bezpieczeństwo: Istota, podstawowe kategorie i historyczna ewolucja. In Bezpieczeństwo Narodowe; Biernat, M., Grzelak, M., Kwaśniewska-Wróbel, J., Perkowska, B., Przybyła, K., Tomaszewski, J., Warchoł, J., Eds.; National Security Office: Warszawa, Poland, 2011; Volume 2. Available online: https://www.bbn.gov.pl/pl/prace-biura/publikacje/kwartalnik-bezpieczens/ wydania-archiwalne/182011/3322,Bezpieczenstwo-istota-kategorie-ewolucja.html (accessed on 23 November 2019).

19. Cokorilo, O. Urban Air Mobility: Safety Challenges. Transp. Res. Procedia 2020, 45, 21-29. [CrossRef]

20. Stańczyk, J. Istota współczesnego pojmowania bezpieczeństwa—zasadnicze tendencje. Rocz. Bezpieczeństwa Międzynar. 2011, 5, 16-20.

21. Krystek, R. Zintegrowany System Bezpieczeństwa Transportu—Diagnoza Bezpieczeństwa Transportu Drogowego; Wydawnictwo Komunikacji i Łączności: Warszawa, Poland, 2009.

22. Krysiuk, C.; Nowacki, G. Miasto, element systemu transportowego kraju. Autobusy 2016, 10, $124-130$.

23. Iwan, S. Wdrażanie dobrych Praktyk w Obszarze Transportu Dostawczego w Miastach; Wydawnictwo Naukowe Akademii Morskiej w Szczecinie: Szczecin, Poland, 2013.

24. Masoumi, S.M.; Kazemi, N.; Abdul- Rashid, S.H. Sustainable Supply Chain Management in the Automotive Industry: A ProcessOriented Review. Sustainability 2019, 11, 3945. [CrossRef]

25. Sanders, R.; Thomas, L. How Systemic Safety Can. Predict Crashes, Vision Zero Cities. Int. J. Traffic Saf. Innov. 2018, 3, 59-62.

26. McCarthy, M.; Gilbert, K. Cyclist road deaths in London 1985-1992: Drivers, vehicles, manoeuvres and injuries. Accid. Anal. Prev. 1996, 28, 275-279. [CrossRef]

27. Morgan, A.S.; Dale, H.B.; Lee, W.E.; Edwards, P.J. Deaths of cyclists in London: Trends from 1992 to 2006. BMC Public Health 2010, 10, 1-5. [CrossRef]

28. Manson, J.; Cooper, S.; West, A.; Foster, E.; Cole, E.; Tai, N.R. Major trauma and urban cyclists: Physiological status and injury profile. Emerg. Med. J. 2013, 30, 32-37. [CrossRef]

29. Good Practice Guide on Urban Freight Transport, 2007, BESTUFS. Available online: http://www.bestufs.net/download/ BESTUFS_II/good_practice/English_BESTUFS_Guide.pdf (accessed on 29 October 2019).

30. Biuro Bezpieczeństwa Narodowego. Available online: https:/ / www.bbn.gov.pl (accessed on 24 October 2019).

31. Dworzecki, J. Bezpieczeństwo ruchu drogowego w Polsce (zarys problematyki). Zesz. Nauk. 2011, 4, 61-79.

32. WYPADKI DROGOWE-RAPORTY ROCZNE. Available online: http://statystyka.policja.pl/st/ruch-drogowy/76562,Wypadkidrogowe-raporty-roczne.html (accessed on 26 October 2019).

33. McDonald, N.; Quan, Y.; Naumann, R. Urban. freight and road safety in the era of e-commerce. Traffic Inj. Prev. 2019, 20, 1-7. [CrossRef]

34. Castillo-Manzanoa, J.I.; Castro-Nuñoa, M.; Fagedab, X. Exploring the relationship between truck load capacity and traffic accidents in the European Union. Transp. Res. E: Logist. Transp. Rev. 2016, 88, 94-109. [CrossRef] 
35. Lemp, J.D.; Kockelman, K.M.; Unnikrishnan, A. Analysis of large truck crash severity using heteroskedastic ordered probit models. Accid. Anal. Prev. 2011, 43, 370-380. [CrossRef] [PubMed]

36. Uddin, M.; Huynh, N. Truck-involved crashes injury severity analysis for different lighting conditions on rural and urban roadways. Accid. Anal. Prev. 2017, 108, 45-55. [CrossRef] [PubMed]

37. Mobility and Transport, Road safety. Available online: https:/ / ec.europa.eu/transport/road_safety/home_en (accessed on 20 January 2021).

38. Mobility and Transport. Available online: https://ec.europa.eu/transport/media/news/2020-06-11-road-safety-statistics-2019 _en (accessed on 20 January 2021).

39. Torfs, K.; Meesmann, U. How do vulnerable road users look at road safety? International comparison based on ESRA data from 25 countries. Transp. Res. F: Traffic Psychol. Behav. 2019, 63, 144-152. [CrossRef]

40. Gandhi, T.; Trivedi, M.M. Pedestrian Protection Systems: Issues, Survey, and Challenges. IEEE Trans. Intell. Transp. Syst. 2007, 8, 413-430. [CrossRef]

41. Methorst, R.; Eenink, R.; Cardoso, J.; Machata, K.; Malasek, J. Single Unprotected Road User Crashes: Europe we have a Problem! Transp. Res. Procedia 2016, 14, 2297-2305. [CrossRef]

42. Hamdani, S.E.; Benamar, N.; Younis, M. Pedestrian Support in Intelligent Transportation Systems: Challenges, Solutions and Open issues. Transp. Res. C Emerg. Technol. 2020, 121, 102856. [CrossRef]

43. Morel, M.; Balm, S.; Berden, M.; van Amstel, W.P. Governance models for sustainable urban construction logistics: Barriers for collaboration. Transp. Res. Procedia 2020, 46, 173-180. [CrossRef]

44. Vrijhoef, R.; Koskela, L. A critical review of construction as a project-based industry: Identifying paths towards a projectindependent approach to construction. In Learning from Experience; New Challenges, Theories and Practices in Construction; Kazi, A.S., Ed.; VTT: Espoo, Helsinki, Finland, 2005; Volume 7, pp. 13-24. Available online: https://www.irbnet.de/daten/iconda/ CIB6804.pdf (accessed on 29 October 2019).

45. Sobotka, A. Zarządzanie logistyczne w przedsięwzięciach budowlanych. Gór. Geoinżynieria 2005, 29, 373-381.

46. Serra, S.M.B.; Oliveira, O.J. Development of the logistics plan in building construction. In System-Based Vision for Strategic and Creative Design; Bontempi, Ed.; Swets \& Zeitlinger: Lisse, Holland, 2003; pp. 75-80. Available online: https:/ / www.researchgate.net/profile/Sheyla_Serra/publication/275345704_Development_of_the_logistics_plans_in_ building_construction/links/553971180cf2239f4e7d92a0/Development-of-the-logistics-plans-in-building-construction.pdf (accessed on 29 October 2019).

47. Lundesjö, G. Supply Chain Management and Logistics in Construction: Delivering Tomorrow's Built Environment; Kogan Page Publishers: London, UK, 2015.

48. Sobotka, A. Logistyka przedsiębiorstw i przedsięzzię budowlanych; Wydawnictwo AGH: Kraków, Poland, 2010.

49. Jaśkowski, P.; Sobotka, A.; Czarnigowska, A. Decision model for planning material supply channels in construction. Autom. Constr. 2018, 90, 235-242. [CrossRef]

50. Ministerstwo Infrastruktury. Polityka Transportowa Państwa na Lata 2006-2025. Warszawa, 2005. Available online: http: / / www.chronmyklimat.pl/ download.php?id=109 (accessed on 12 July 2019).

51. Małecki, K.; Iwan, S. Zastosowanie rozwiązań telematycznych jako czynnik warunkujący efektywne zarządzanie miejskim transportem towarowym. Logistyka 2014, 3, 4128-4136.

52. Łapko, A. Urban tourism in Szczecin and its impact on the functioning of the urban transport system. Procedia-Soc. Behav. Sci. 2014, 151, 207-214. [CrossRef]

53. Strategia Rozwoju Sektora Transportu Województwa Zachodniopomorskiego do Roku 2020. 2010. Available online: http: / / eregion.wzp.pl/ (accessed on 5 April 2016).

54. Sosik, K. Koncepcja sieci odcinkowych pomiarów prędkości w województwie zachodniopomorskim. Autobusy 2018, 12, 390.

55. System Zarzadzania Ruchem w Szczecinie. Available online: http://pbr.szczecin.pl/chapter_202051.asp (accessed on 21 November 2018).

56. Policja Zachodniopomorska. Available online: http://www.zachodniopomorska.policja.gov.pl/sz/ (accessed on 26 October 2019).

57. Pułkowski, M. Wskaźniki oceny bezpieczeństwa w ruchu drogowym. Pr. Wydz. Nawig. Akad. Morskiej W Gdyni 2018, 33, 53-62.

58. Szczecin City Hall, Comprehensive Traffic Research 2016. Available online: http://bip.um.szczecin.pl/chapter_11124.asp (accessed on 22 January 2021).

59. Generalny Pomiar Ruchu 2000. Available online: https://www.gddkia.gov.pl/pl/988/gpr-2000 (accessed on 22 January 2021).

60. Kiba-Janiak, M.; Cheba, K. Information system for city logistics. The case of Poland. Transp. Res. Procedia 2019, 39, 160-169. [CrossRef]

61. Pokorny, P.; Drescher, J.; Pitera, K.; Jonsson, T. Accidents between freight vehicles and bicycles, with a focus on urban areas. Transp. Res. Procedia 2017, 25, 999-1007. [CrossRef]

62. Kijewska, K.; Torbacki, W.; Iwan, S. Application of AHP and DEMATEL Methods in Choosing and Analysing the Measures for the Distribution of Goods in Szczecin Region. Sustainability 2018, 10, 2365. [CrossRef]

63. Kijewska, K.; Iwan, S. Analysis of the Functioning of Urban Deliveries in the City Centre and its Environmental Impact Based on Szczecin Example. Transp. Res. Procedia 2016, 12, 739-749. [CrossRef] 
64. Urbanity. Available online: https://www.urbanity.pl (accessed on 24 October 2019).

65. Thompson, R.G.; Hassall, K. Implementing high productivity freight vehicles in urban areas. Procedia-Soc. Behav. Sci. 2014, 151, 318-332. [CrossRef]

66. AlKheder, S.; AlRukaibi, F.; Aiash, A. Risk analysis of traffic accidents' severities: An application of three data mining models. ISA Transactions 2020, 106, 213-220. [CrossRef] [PubMed] 